Editorial

\title{
Transfusion in the Spanish Civil War: Supply and demand, the role of the "blood transfusion officer" and British planning for the outbreak of the Second World War
}

\section{A B S T R A C T}

During the First World War blood transfusion progressed from being a rarely used treatment to a major component of the resuscitation of exsanguinated casualties, relying on local donation and availability of medical expertise. In the 1920s and early 1930s, clinical use of transfusion gradually increased supported by growing civilian, often volunteer, blood donor systems.

The Spanish Civil War (1936-1939) introduced the first systematic use of aerial bombardment to intimidate the civilian population and to destroy infrastructure; it also saw more mobile battlefronts, replacing the relatively static trench warfare of 1914-1918. New measures for the delivery of transfusion services emerged rapidly from primitive beginnings. These included large civilian blood donor organizations providing anti-coagulated "stored" blood for civilian and military medical use and land delivery services to civilian and military hospitals. Surgical units for the emergency management of casualties were required to be agile in moving as battlefronts evolved and carefully concealed to avoid air attack. Ideally the blood supply would follow.

Under threat of a wider European conflict in 1938-1939, British authorities started developing plans for transfusion support in the management of civilian casualties of air attack and military casualties of armed conflict. The involvement, directly and indirectly, of British and other volunteer physicians returned from Spain, together with their Spanish colleagues, ensured that awareness of the Spanish experience was available to the British authorities. The system that was eventually put in place involved a civilian blood donor capability with one centre dedicated particularly to military supplies. Separate distribution systems were organized for civilian and military purposes, with the latter including distribution overseas by air.

The military system delivered blood and components through a supply chain to mobile field transfusion units under command of a medical officer specially trained in transfusion and resuscitation, supporting mobile surgical units in the immediate rear of battlefronts. The broad principles developed in Spain (1936-39) for delivery of military blood transfusion practice still support current measures in battlefield casualty resuscitation.

\section{Introduction}

The Spanish Civil War began in July 1936 when a right-wing military coup was launched against the elected Republican government. The rebels ("Nationalists"), led by General Francisco Franco, failed to take complete control of the country, leading to a bitter civil war, lasting almost 3 years, causing half a million deaths, and for the first time a war in which civilian deaths may have exceeded those in the armed forces [1].

The forces on the Nationalist side received material and military support from Germany and Italy, and the Republican side, from the Soviet Union and Mexico. Other countries including France, the United Kingdom and the Commonwealth, and the United States, recognized the Republican Government as the legitimate government of Spain, but pursued a policy of "non-intervention". Despite this policy, Socialist and Communist interests in these and other countries actively supported the Spanish republic and sponsored volunteer participation from whom arose the fighting force known as the International Brigades. Among those volunteers were many physicians, nurses and others who became involved in the care of casualties, military and civilian.

The Civil War became a proving ground for strategies, tactics and services later employed in the Second World War (WW2). From a military point of view, for example, the Spanish conflict saw the first use of massive deliberate aerial bombardment (by the insurgent Nationalist forces, supported by German and Italian units) to destroy infrastructure and intimidate and demoralize civilian populations. The evolution of medical services in Spain provided significant new information on a variety of medical issues including, for example, the forward positioning of mobile surgical teams, and the management of compound long bone fractures in the prevention of gas gangrene $[2,3]$. Among the services where experience proved particularly valuable in developing WW2 policies was the field of blood transfusion support for war surgery, both in the adaptation and enhancement of civilian blood donor services for military use, and in the delivery of transfusion support close to battlegrounds to facilitate prompt transfusion of exsanguinated casualties.

Early in the First World War (WW1) blood transfusion was a somewhat rare clinical event, usually dependant on the use of devices for direct transfer of blood from donor to recipient, requiring time, and technical and surgical expertise. By 1918, the value of prompt transfusion of anticoagulated stored blood in the management of "shock" and hemorrhage in war casualties was established [4] but dependent on readily available military personnel as donors, and local storage and transport arrangements [5-8]. Between the wars clinical use expanded relatively slowly [9] and emphasis was more on the establishment of community blood donor programs [10,11].

In the Spanish conflict the sudden need for blood supplies led to rapid development without the opportunity for advanced planning. On the Republican side, there evolved a civilian volunteer blood donation system, together with the clinical practice of blood transfusion to military and civilian casualties, based as much or more on availability of blood and professional expertise as on clinical need. Blood donor 
programs established in Barcelona and Madrid have been described (vide infra) and provide an account of the development of the supply of stored blood for transfusion. Details of the day to day transfusion of blood in support of surgical care of casualties are less well documented. Nevertheless, available information does provide some insight into practical aspects and problems of transfusion under war conditions.

This review seeks to explore the evolution of transfusion practice in the Spanish Civil War as developed by the Republican side, and the impact on transfusion policies introduced in anticipation of WW2.

\section{The blood donor programs}

The Barcelona Transfusion Service was established by the Catalan physician Dr. Frederic Duran Jordà and operated from August 1936 to January 1939 [12-15], serving both civilian and military populations. Duran's most important contribution lay in the sophisticated supply of citrated blood. In $21 / 2$ years of operation the Barcelona Service registered 28,900 donors and supplied 9000 litres of blood or about 27,000 units of about $300 \mathrm{~mL}$. Collections were made predominantly from group O ("universal") donors to bypass the need for pre-transfusion compatibility testing. The first consignment of blood to the front was made in September 1936, 7 litres over $300 \mathrm{~km}$ to the Aragon front in a refrigerated fish truck15]. Later, weekly deliveries of blood were made in refrigerated trucks, some over distances of several hundred kilometres, to advanced hospitals near battle fronts and to base hospitals in the rear. Advanced hospitals (i.e. close to the front) were fitted with refrigerators that could store up to 15 units and base hospitals with capacity for up to 50 units $[3,16]$.

The other major republican transfusion service, the Madrid Blood Transfusion Institute, was established by Canadian surgeon Dr Norman Bethune (by building on the work begun by the Republican army transfusion service already operating in the Madrid Medical School under Dr. Gustavo Pittaluga). Bethune headed the Madrid institute between November 1936 and May 1937 [17-21], and thereafter it was operated by Spanish physicians appointed by the authorities (Sanidad Militar) under the direction of Dr. Vincente Goyanes [22]. It was described in detail by Saxton who visited it in March 1937 [17,23] and served both military and civilian (mainly air-raid) casualties. Donations were tested for syphilis, stored "just above freezing" for up to 3 weeks with pre-transfusion warming recommended [17,24]. It is estimated that in 1937 there were 3875 registered donors, an average of 100 litres of blood were transfused each month and a total of 1900 transfusions performed. Estimates provided by Dr. Vincente Goyanes, Bethune's successor as head of the Servicio Hispano-Canadiense de Transfusion de Sangre, suggest that $5000400 \mathrm{~mL}$ "flasks" were transfused [18] and Pittaluga [22] also estimated that the Madrid Institute supplied blood for over 4500 transfusions.

\section{Blood transfusion in support of treatment of casualties}

In contrast to the quite detailed descriptions, particularly by Duran, of the collection of blood, there is very little information on transfusion in the management of war casualties. During his time as chief of the Madrid Institute, Bethune performed transfusions himself on both military and civilian casualties and pressed for early administration of transfusion [25]. However, he did not provide more than brief anecdotal accounts of transfusions, and of the clinical circumstances under which they were administered. Early in the War Duran did perform transfusions himself at the front but later mobile teams were trained to carry out the procedure.

However, British doctor Reginald Saxton recorded his experiences with transfusion practice at some of the major battles of the Spanish Civil War, describing the evolution of his practical knowledge, and the measures used to provide transfusion support in the dire circumstances under which he and his surgical colleagues operated. These experiences are documented in articles and letters published in the Lancet
[17,25-27], in personal notes and in letters to his family and his local English newspaper, and in a series of interviews recorded by the Imperial War Museum in 1994 [28]. Saxton's records remain the only known detailed accounts of transfusion practice under the day to day conditions of the Spanish Civil War.

Reginald Soames Saxton was born in Cape Town, South Africa on 13 July 1911. The son of a Botanist, Saxton spent a privileged childhood in India before being sent to Repton Public School in Derbyshire. He was uncomfortable with upper-class prejudices and the punitive behavioural mores of the Public School culture, developing a keen sense of social justice. In 1929, he entered Cambridge University with a view to a medical career. This was a time at Cambridge when there was a strong undergraduate interest in Communism and Saxton himself acknowledges the presence among his contemporaries of "notorious people like Philby and co. [...] spies and Soviet agents and heaven knows what" [28]; Saxton later became an active member of the Communist Party of Great Britain. Completing his medical training at St. Bartholomew's Hospital in 1935, he was junior staff member there when the Spanish Civil War broke out. Early in August 1936, he attended the inaugural meeting of what would become the Spanish Medical Aid Committee (SMAC) and volunteered his services. Saxton's previous experience with blood transfusion during his clinical career amounted to only a single episode [28].

On the eve of his departure for Spain in September 1936, Saxton gave an interview to the press: "We are going to help the wounded on both sides. We cannot, of course park on both sides, so we shall go on the side of the Government, with whom we have sympathy as the democratically elected Government of Spain. We have no sympathy for the rebels who, we believe, are trying to establish a military dictatorship over the Spanish people, but we shall assist the wounded rebels all the same" [29].

Saxton arrived in Spain in late September 1936 and was stationed at Grañen, Huesca near the Aragon battlefront, although there were at that time little hostile activity and his medical work consisted largely of that of a local medical practitioner. The SMAC contingent eventually became part of the International Brigades Medical Service, under the control/direction of the Servicio Sanitario de la Republica.

The first major battle involving Saxton's team was a rebel-led offensive at Jarama (Fig. 1), south-west of Republican-held Madrid, which lasted through most of February, 1937. A Divisional hospital was set up in a large villa $60 \mathrm{~km}$ southeast of Madrid and $5 \mathrm{~km}$ from the front line. Saxton's account of his experience was published in the press at home: "The crackle of machine guns goes on all the time. We have about 60 beds but can put up 100 wounded or more...." [30]. The medical team included three surgeons as well as medical students who acted as anesthetists. Saxton was the only physician without surgical training and was assigned as triage officer and team transfusion officer [27]. At the outset, he was concerned about the lack of provision for transfusion; the unit had little appropriate equipment and relied upon donors among the staff for supplies of blood. At this time Bethune visited, bringing stored blood and offering to provide Saxton's team with regular supplies. He returned soon afterwards with a refrigerator with capacity for up to 20 half-litre bottles, with basic re-usable transfusion equipment for direct transfusion including a two-way Jubé [31] syringe device with afferent and efferent connections for donor and recipient, and with grouping sera. During lulls in activity, as a precaution Saxton grouped staff, soldiers and local villagers as potential donors. However, once Bethune's Madrid service provided regular supplies, they generally proved sufficient without resorting to staff donors $[27,28]$.

The battle of Jarama ended inconclusively at the end of February. Saxton notes that he did not have complete records of transfusions during this period but indicates that deaths among transfused casualties were less than would have been anticipated without transfusion. He suggests that improvement in the fatality rate might be achieved by withholding transfusion very unlikely to affect the outcome, and to 


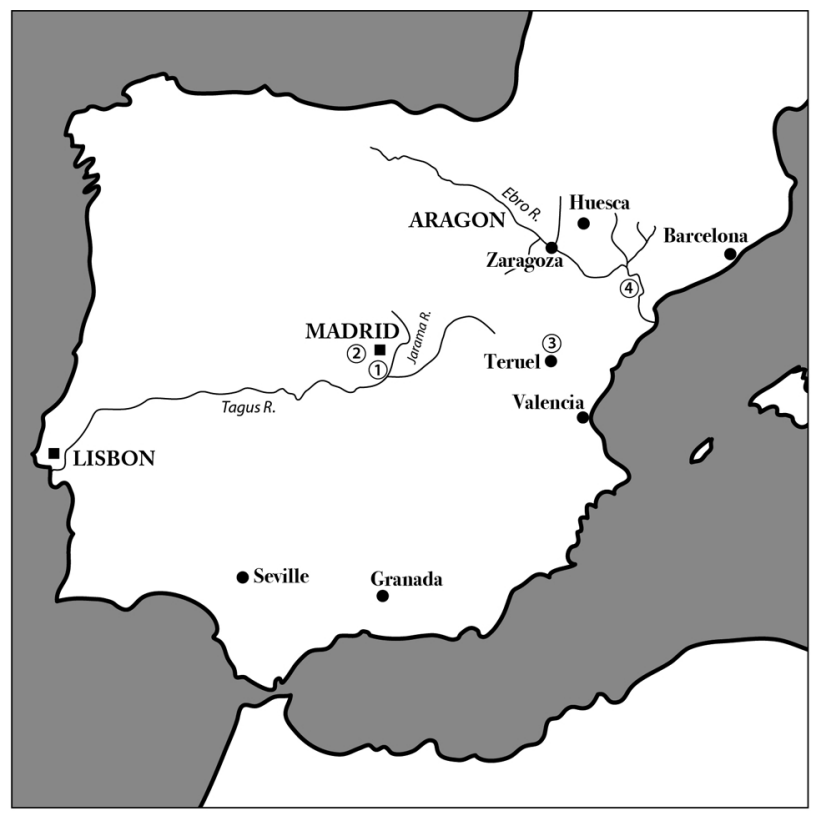

Fig. 1. Map of the Iberian Peninsula showing the principal cities and locations of battles at which Reginald Saxton was present and involved in transfusion. No. 1, Jarama, February, 1937; No. 2, Brunete, July, 1937; No. 3, Teruel, December, 1937 - February, 1938; No. 4, Ebro, July - September, 1938. Major blood donor services were operated in Barcelona, Madrid and Valencia.

administer large and repeated transfusions to those with "very severe shock" who might survive [17]. In a letter to the (Berkshire) Chronicle, written on February 20th 1937 [30] Saxton writes: "I have been made chief blood transfusor (sic) to the hospital, and on full days give about 10 transfusions a day. Probably a few lives have been saved this way. Some unfortunately were only prolonged for a few hours......we are having a big rush of wounded again, dealing with over fifty cases a day".

It became apparent quite early in the war that hospitals were regarded by the nationalist forces and their German and Italian allies as targets [32,33]. Bethune noted the removal of the Red Cross emblems as a precaution against a hospital being identified as a target [24] and measures to conceal hospitals and related activities became necessary.

Between battles, periods of relative military inactivity provided opportunity for organizational improvements. On March $7^{\text {th }} 1937$, Saxton visited the Madrid Blood Transfusion Institute, making detailed notes of policies and procedures that formed the basis of his description of the Madrid Institute $[17,23]$. The medical staff were recorded as Drs. Bethune, Goyanes, Sanz, Culebras and Loma, 5 nurses and 4 or 5 secretariat and interpreters. Supply rate at the time was about 400 litres a month. He lists the content of kit for "The Travelling Blood Transfusion" brought by Bethune's team [34] when called to deliver transfusion: "Glass slides, grouping serum, Frankel's needle. Bottle of alcohol. Jug for hot water (to warm units prior to transfusion). Two $500 \mathrm{ccs}$ bottles of blood groups II and IV Moss. Electric torch. Thermometer. Tourniquet. 2 sets of sterile Jubé syringes needles and rubber tubing".

While on leave in England and Paris Saxton acquired additional Jubé syringe transfusion devices, and Henri-Jouvelet [35] rotary pump devices for either arm-to-arm or stored blood transfusion and which incorporated a flow meter to measure volumes of blood transfused.

On his return to Spain in May, 1937, Saxton helped to establish an advanced casualty clearing hospital in the Sierra de Guadarrama north of Madrid and managed a transfusion service, before being involved in the development of a large field hospital in a monastery north west of Madrid in July, for medical support in a major Republican offensive at the battle of Brunete (Fig. 1). There were 3 operating rooms and 5 surgical teams (one led by Dr. Douglas Jolly (vide infra)), an X-ray unit and a blood transfusion service under Saxton's direction. Staff underwent blood grouping in advance so as they could serve as potential donors. There were large numbers of casualties, involving continuous resuscitation and surgical activity for days at a time and Saxton "once more took to transfusions, now as a whole time job". Here transfusions were given so frequently, and sometimes in such quantity, that the supply from Madrid often ran out, and Saxton was taking blood from the already overworked staff. He explains the procedure: "When using donors on the staff, we have always given the blood as a direct transfusion - i.e. from arm to arm" favouring use of the Henri-Jouvelet device [27]. In a letter dated July $21^{\text {st }}$, he reports performing during the preceding two weeks, 70 or 80 transfusions, mostly "bottled blood" from Madrid, but often directly from staff $[27,36]$.

Saxton's growing appreciation of the value of transfusion is conveyed by his comment that "transfusion is more important in the management of shock than previously realised" [28]. The battle ended on July $25^{\text {th }}$ with the Republican gain of about 75 square kilometres of territory at a cost in battle of more than 20,000 lives.

At this point, Saxton returned briefly to England on leave, writing to his mother on July $29^{\text {th }}$, the eve of his departure from Spain [36] "I don't want to be in England more than a fortnight or so, because I feel I have a very useful function here during battles. We've had a terribly busy time altogether, far more so than ever before and my job of blood transfusions has more than ever been necessary". Later, in October, he notes "There is really no brand new discovery used in the blood transfusion work...what was new was its utilization on such a scale" [36].

Saxton had begun to train assistants allowing him to concentrate on setting up the transfusion rather than carrying out the infusion itself. In the autumn of 1937, Henry Rubin joined the team. Rubin, a Californian with a scientific background in biology, had been previously involved in setting up laboratory testing. An Italian technician, Jean Picone, with experience at Bethune's Madrid Institute, was also recruited [37]. At this point, Saxton conceived of a mobile laboratory equipped to carry out simple laboratory work including bacteriological and parasitological investigations, blood group testing, elementary haematology and biochemistry testing, urinalysis and, particularly, refrigerated storage of blood for transfusion $[38,39]$. Such a mobile laboratory and transfusion service would complement the growing use of the auto-chir, a concept developed by the French in WW1 (a combination of "automobile" and "chirurgie") and better suited to the situation in Spain of a 

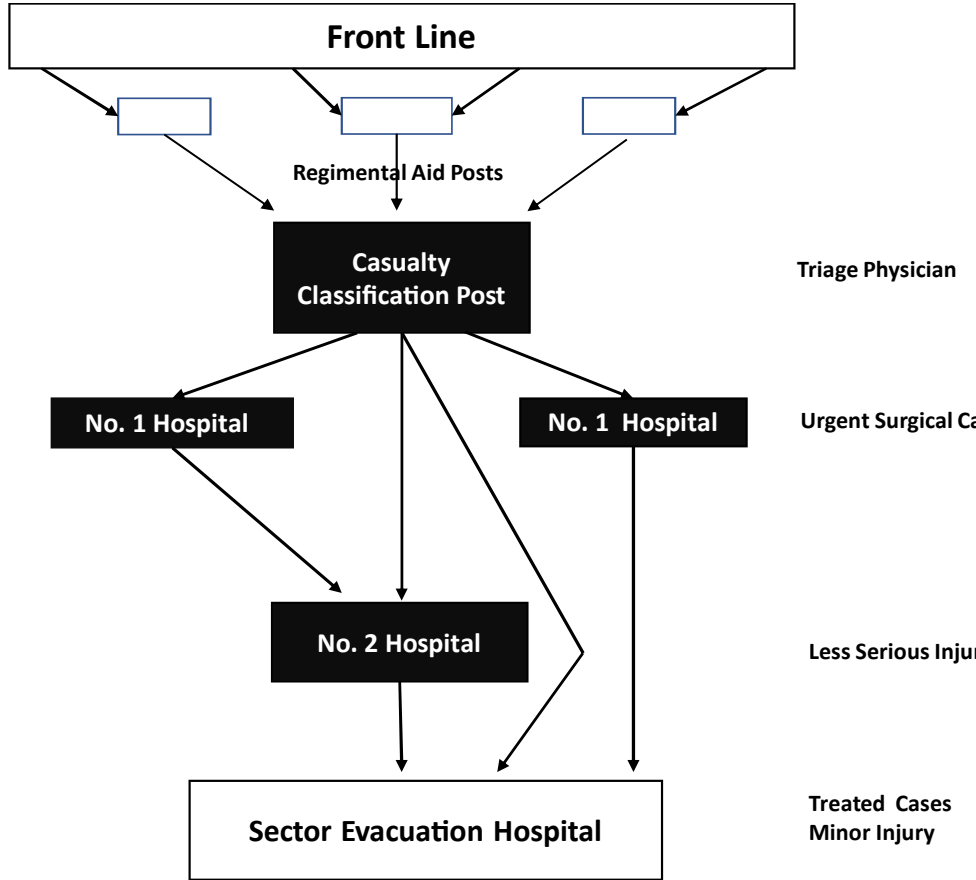

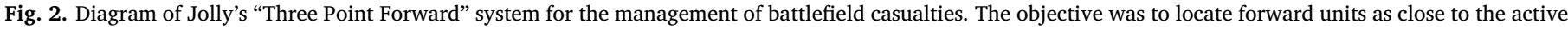

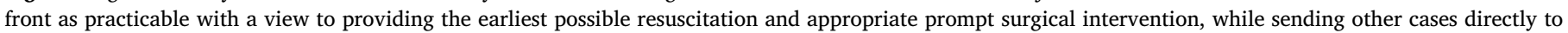
services in the rear $[33,47,48]$.

constantly moving battle front, compared with the relatively static fronts in Europe in WW1. The auto-chir involved two vehicles, one for the surgical team and one carrying all the equipment needed to set up an advanced surgical unit (No.1 Hospital, Fig. 2) [40,41].

In November 1937 a large ambulance, severely damaged but with the main frame ("chassis") and engine intact, was rebuilt to accommodate these services (Figs. 3 and 4). This mobile laboratory would enable the transfusion team to move promptly close to the battlefront, thus avoiding delay and the necessity of making frequent journeys, often over rough terrain, to supply blood to forward medical units. This would also reduce the risks of loss or damage to laboratory equipment and supplies. "The laboratory, then, as far as the surgical units are concerned, is just one further step in the improvement of the blood transfusion service" [26]. In the spring and early summer of 1938, Saxton's "Travelling Laboratory" investigated about 2000 diverse specimens; a particular challenge, successfully met, was proving that local farmers were adding water to supplies of local goat milk to the local hospital [28].

In mid-December 1937, the Republican forces attacked and surrounded Teruel (Fig. 1), over 1,000 m above sea level. Fierce fighting, often in bitterly cold conditions, continued until February 1938, resulting in tens of thousands of casualties (from war and cold) on both sides before the Nationalist forces prevailed and recaptured Teruel. Saxton's team was supporting the work of three surgeons (an American, a Belgian and a Catalan) [42]. Blood was in short supply and the situation was exacerbated by loss of blood storage capacity due to failure of the electricity supplies [43] and at times transfusion depended on direct transfusion from staff. Saxton had been aware of the practice in the Soviet Union of recovering cadaver blood for transfusion [44] and actually experimented with blood collection from fatal casualties $[45,46]$. However, it appears that he never actually performed such transfusion as his procedures were never sufficiently well developed.

The last major offensive of the war in the summer of 1938 was at the River Ebro (Fig. 1). It was a Republican initiative to reunite the divided north and south areas it still held. Surgical units were established in a hospital in a large cave near the river, and later in a railway tunnel, to provide protection from bombing. The mobile transfusion service was stationed in a nearby olive grove where it was camouflaged with tree branches. The transfusion load was heavy. The chief surgeon was the New Zealander, Douglas Jolly, with whom Saxton had worked previously at the battle at Brunete. Jolly [47] was clearly impressed with the work of Saxton's transfusion team in support of care of the wounded, emphasizing the need for availability in the early treatment at surgical units near the front. He later spoke of the great advance in technique represented by the use of conserved blood "on a large scale" and "delivered daily to the field" [48].

Blood supplies for the Ebro campaign came from Barcelona. Saxton describes the "ampoules" of blood containing 300ccs of blood and 200 ccs of compressed filtered air, with rubber tube, filter, drip chamber and air trap, needle and connecting adaptor. The blood flow was enhanced by the air pressure and the rate of infusion controlled by a screw clip [27]. In his generally favorable appraisal of Duran's Barcelona Blood Transfusion Service, Saxton notes that rigors were frequent ("about half the cases") with transfusions in August of 1937 and 1938, with some units received at the Ebro offensive showing a "brown colour" indicating "heavy growths" [14].

Negotiations to end the Civil War were begun and in September 1938 the order was given for the withdrawal of all International volunteers. The British medical teams were repatriated, bringing their hard-earned experience back to a country anticipating the outbreak of war in Europe. This was a period of tension in the aftermath of the annexation of Austria by Germany in March 1938, followed by the illfated Munich Agreement in September. Among those Republicans escaping from Spain to Britain were Duran and Trueta, who went on to assist the British authorities in their war preparations and to embark on distinguished careers, Duran as a Pathologist in Manchester [49] and Trueta as Nuffield Professor of Orthopaedic Surgery in Oxford [50]. Dr. Goyanes by contrast was incarcerated but later released [18].

On his return, after a spell in General Practice, Saxton became assistant Medical Officer of Health for Brighton with special responsibility for "civil defence". He wrote to Col. Whitby at the Army Blood Supply Depot in Bristol (vide infra) describing his experience in Spain but 


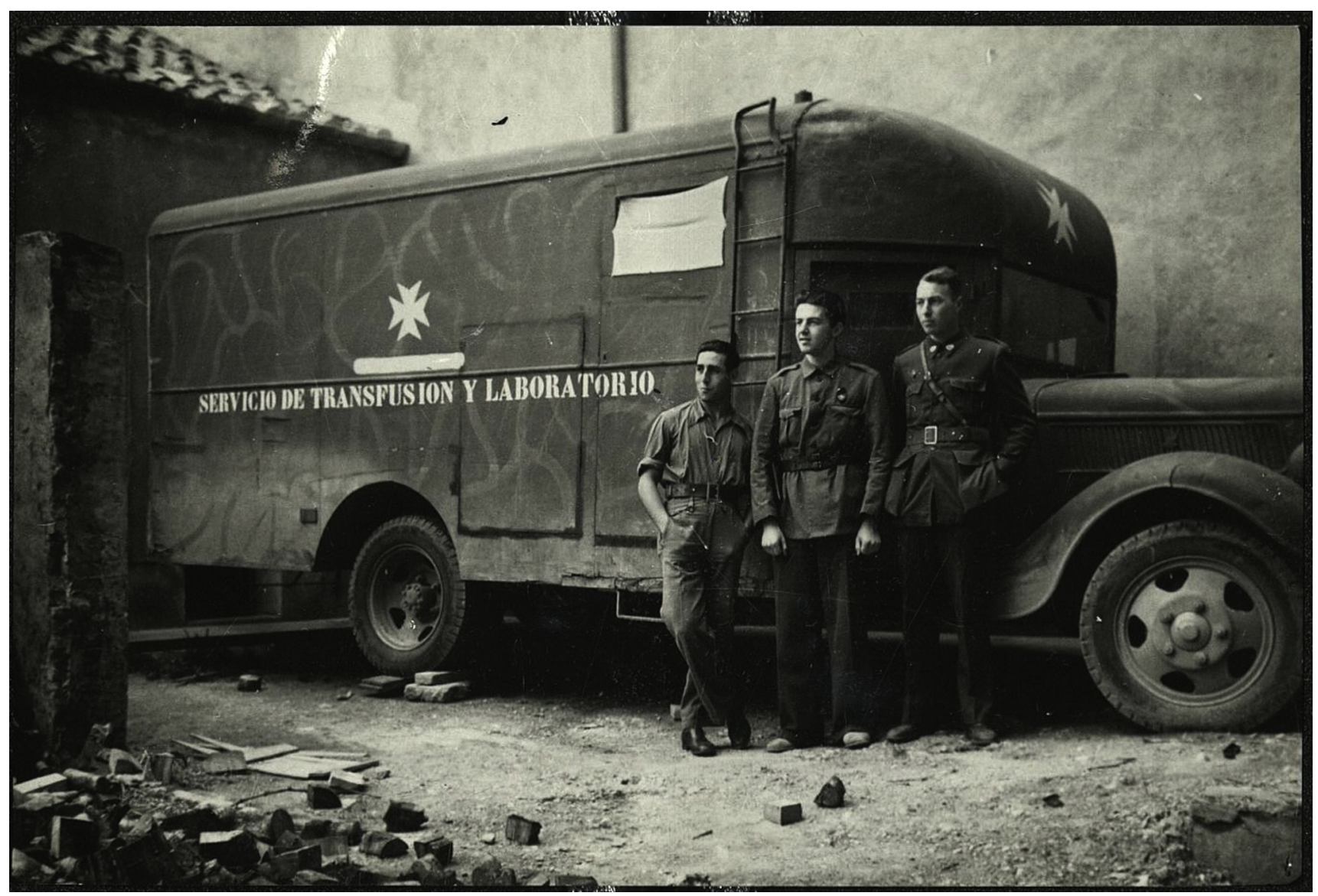

Fig. 3. Reginald Saxton's "travelling laboratory". Dr. Saxton (right) with Henry (Hank) Rubin (center) and his Spanish driver, Paco. With permission, from the Archive of the Trades Union Congress, Modern Records Centre, University of Warwick Library (MSS 292/946/42/13).

apparently there is no evidence this was acknowledged [28]. However, he was called up to the Royal Army Medical Corps in November 1941 and was posted to Arakan in northwest Burma as Lieutenant where he was officer in charge of a Field Transfusion Unit and subsequently to No. 2 Advanced Base Transfusion Unit in Calcutta. He was Mentioned in Despatches and retired with the rank of Major, returning home in 1945 [51]. Thereafter he worked in General Practice near Brighton, and later in Wales with Dr. Julian Tudor-Hart, the son of his old comrade in arms from Spain, the surgeon Alexander Tudor-Hart. Saxton retired in 1976 but remained politically active with the Campaign for Nuclear Disarmament and in opposition to the 1991 Gulf war. He died in 2004 [52].

\section{Transfusion - quantities and effectiveness}

It appears that approximately 12,0001 of blood, about 27,000 units of $300 \mathrm{~mL}$ and 5000 units of $400-500 \mathrm{~mL}$, or 32,000 units in total, were made available within the Transfusion Service of the Republic during the years of warfare. Records and details of distribution, use and effectiveness are fragmented. Also, when supplies of stored blood were exhausted, transfusing staff were resorting to the more time-consuming use of direct transfusion from other staff and civilian donors, and there is no record of the numbers of such transfusions carried out.

Quantities of blood transfused to individual recipients were seldom recorded. Pittaluga [22] comments that 250-300cc were often transfused but rarely were more than 500cc given. Saxton [17] records transfusing 99 patients in 7 weeks, of which 12 received more than one transfusion, but the number of units involved is not stated. Duran [13] describes giving up to $3500 \mathrm{c.cm}$ (sic) of group O blood to a non-group
$O$ recipient without adverse transfusion effects, but this statement is made in the context of the safety of his pooled group $\mathrm{O}$ universal donor policy. In a report to the British Red Cross Society Duran [53] describing his transfusion administration method, states: "About $10 \mathrm{~min}$ is usually taken to inject $300 \mathrm{ccs}$, and if necessary, the transfusion continued until from $300 \mathrm{ccs}$ to $1,200 \mathrm{ccs}$ or even more have been given."

Jolly [47] describes 243 consecutive cases who received "one or more" transfusions, but numbers of units included in a transfusion are not stated. Elsewhere [48] he states that overall in Spain 970 "abdominal cases" and many other serious cases on whom he operated received one or more transfusions.

Saxton estimated that he personally performed 239 transfusions [17].

There do not appear to be any data on the proportions of donated blood issued for treatment of civilian as opposed to military casualties, although it is known that both Madrid and Barcelona were supplying citrated blood to civilian hospitals [3,24].

Estimates of the effectiveness of transfusion are also hard to determine. In Saxton's [17] series of 99 patients, 61 died and of the 12 given more than one transfusion, 11 died. Saxton remarks that the mortality, a little over $60 \%$ in the transfused cases, would have been expected to have been more than $90 \%$ without transfusion. In Jolly's series of 243 patients with a variety of injuries, defined by the principal viscus involved and from a variety of projectiles and who were all transfused, mortality was about $50 \%$. Jolly [47] observes, somewhat drily, that "although there were no controls, there is every reason to believe many of the men evacuated to base hospitals owed their lives to the conserved-blood method of transfusion". 


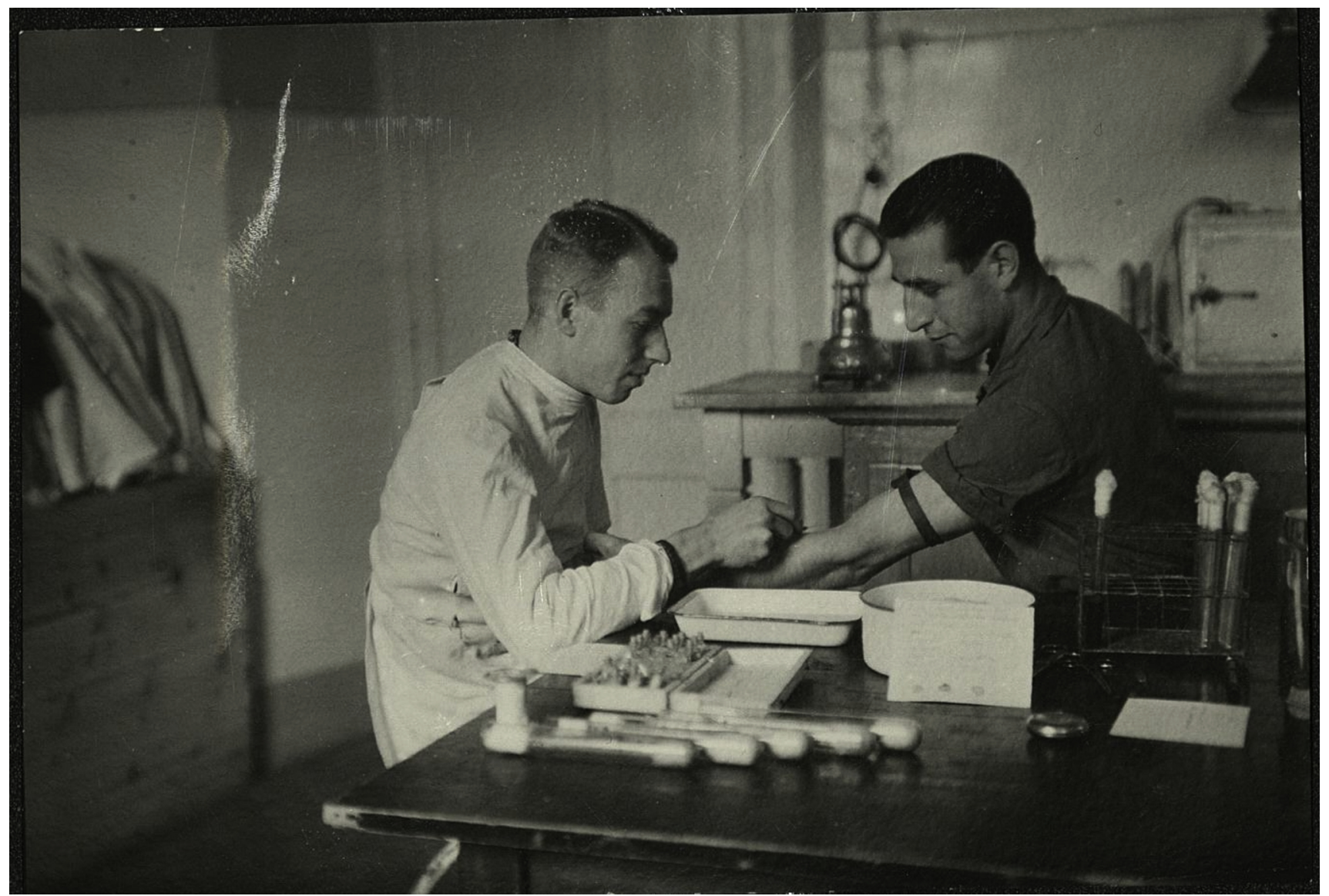

Fig. 4. Dr. Saxton in his "travelling laboratory", taking a blood sample from a prospective blood donor. With permission, from the Archive of the Trades Union Congress, Modern Records Centre, University of Warwick (MSS 292/946/42/13(va)).

\section{The impact of events in Spain on delivery of British transfusion} services in the Second World War

The principal advances in transfusion practice that developed in 1936-1938 in Spain with potential to influence British practice were two-fold. Firstly, a voluntary blood donor system based on the urban civilian population was implemented for procurement of anticoagulated "stored" blood in quantity for treatment of civilian and military casualties, with delivery organized to supply the battlefield medical teams as well as for the care of civilians. Secondly, there evolved a mobile blood transfusion service under the direction of a Blood Transfusion Officer capable of providing prompt transfusion resuscitation and support for mobile acute front-line surgical units.

In the post-WW1 period transfusion in Britain had been largely dependent on "donation as required" through panels of registered volunteers rather than on stocks of pre-donated stored blood [10]. With the apprehensions of war aroused by the aggressive German policies, particularly after the Munich Agreement, and with awareness of the consequences of aerial bombardment of civilian populations in Spain, there was growing appreciation of the need a large stored blood transfusion capability for both civilian and military purposes. Two individuals, Janet Vaughan and Lionel Whitby, played central roles in implementing the policies instituted to achieve these objectives. Both were London-trained clinical pathologists with special interests in hematology. Dr. Janet Vaughan had trained at University College Hospital and at the Thorndike Laboratory in Boston, had published her classic textbook, The Anaemias, in 1934 [54], and was now at the British Postgraduate Medical School at Hammersmith [55]. Dr. Lionel Whitby had trained at the Middlesex Hospital and was co-author of a recent textbook of hematology [56]. He had been a "machine-gun officer" in
WW1, and had had a wounded leg amputated after barely surviving major blood loss, his treatment involving transfusion $[10,57,58]$.

Acting on behalf of the Ministry of Health, and specifically recognizing the "success achieved in the Civil War in Spain where stored blood was carried to Army medical units in the field and was also used for the treatment of air-raid casualties", in September 1938 the Medical Research Council (MRC), with Vaughan playing a vital role, undertook to establish four Blood Supply Depots in London suburbs [59].

Vaughan was also involved with the SMAC [60] and well-informed on the conduct of the Civil War and the functions of the medical units there. Thus, she was aware not only of Saxton's developing interest and abilities in blood transfusion both through his publications [17,25-27], and his reports to the SMAC $[38,39,42,61]$, but also of the model that Duran's Blood Centre [12,13] in Barcelona would form for the MRC initiative in London. Furthermore, when Duran and Trueta fled Catalonia for London (as ardent Republicans at risk) she assisted them in settling in England while at the same time benefiting from their knowledge and experience. In particular, Duran (and his family) stayed in London at her home while he worked with her at Hammersmith [60]. Vaughan's leading role in the organization of a major stored blood supply for transfusion began by convening repeated meetings (often at her home) attended by pathologists from the major London hospitals, Percy Oliver of the British Red Cross BTS [10], Professor John Beattie of the Royal College of Surgeons (vide infra), Lionel Whitby and officials of the MRC. The group moved from "no official status" to becoming the Sub-committee on Blood Transfusion of the Emergency Pathology Committee of the MRC acting for the Ministry of Health. Items considered included equipment, locations, storage conditions, delivery, reagents, staffing, budget, donor recruitment and publicity [62]. Much of the detail of the proposed operation of the Emergency Blood 


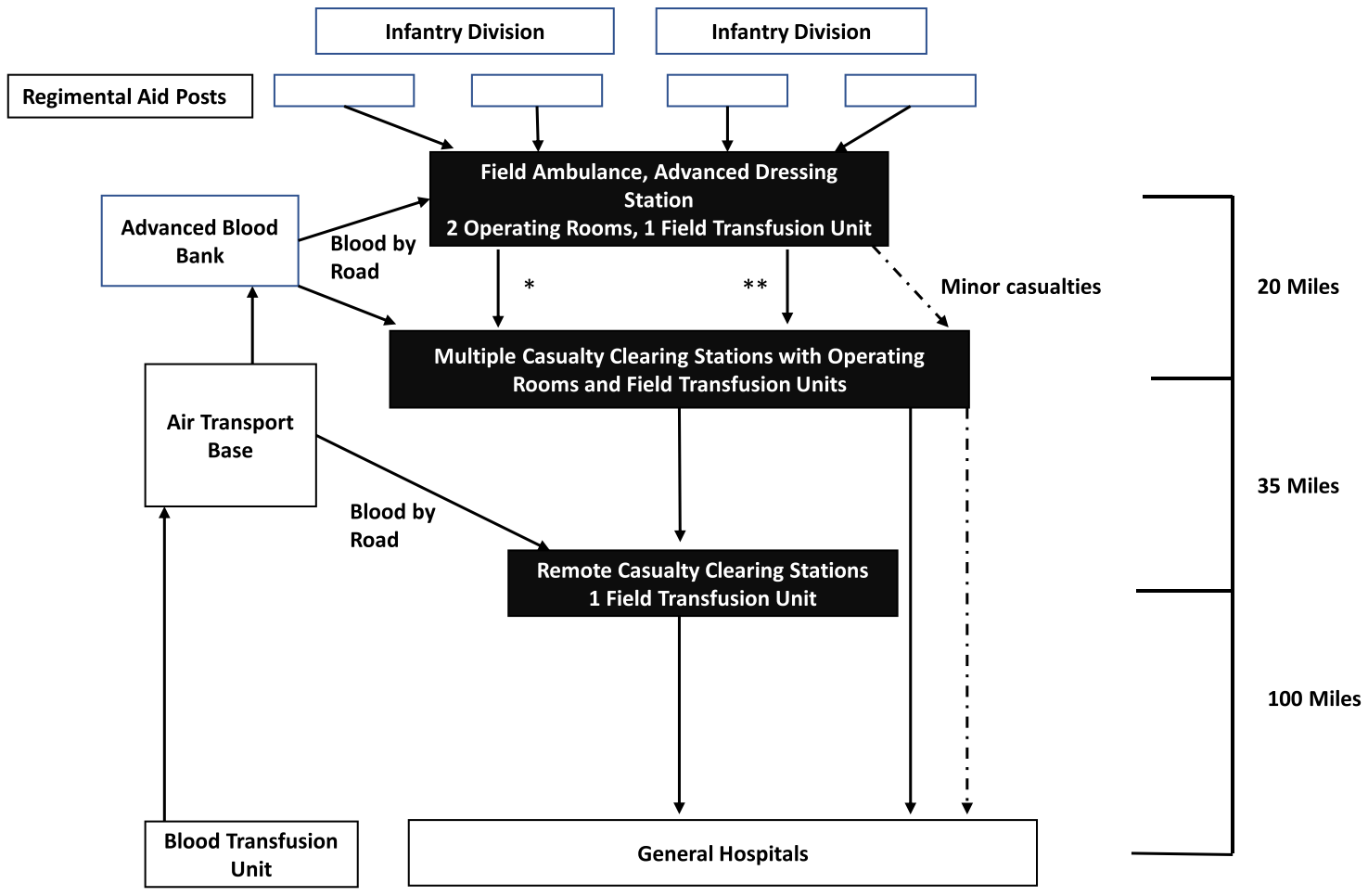

Fig. 5. An interpretation of the Blood Transfusion Service availability at the Battle of Mareth, Tunisia, March 1943, as presented in the post-war history of the ABTS [74]. "Group 1" cases* defined as requiring immediate resuscitation including transfusion support would only be sent on to Casualty Clearing Stations (CCS) after emergency management. All other cases*** would be sent straight through to CCS or would be evacuated to "general" hospitals further in the rear [74].

Transfusion Centres was based on Vaughan's own research [63-65], on the information available on the Barcelona Centre, both published [12-14] and personal, and by Saxton [17] on Bethune's Madrid Institute. By June 1940 the four London Depots had enrolled 113,500 donors with the potential to collect 2200 "bottles" a week, and a normal civilian demand for 500 a week [10].

Following the German advance and evacuation of the British Expeditionary Force (BEF) from Europe in June 1940, realization of a more immediate potential for air attack of civilian targets led to the accelerated establishment of Regional Blood Transfusion Services, building where possible on pre-existing services [59]. Saxton's experience in Spain led him to offer advice with regard to a pre-war initiative in Leeds [66]. He recommended that the blood supply process be kept physically and administratively separate from hospital operation to prevent competition between simultaneous donation and transfusion activity from overwhelming staff and structure.

At the same time as the decision was made to establish civilian Emergency Blood Depots it was decided to develop an Army Transfusion Service independent of the civilian services. A meeting was convened by the President of the Royal College of Surgeons at the request of the Director General Army Medical Services, Sir William MacArthur. Present were two academic Fellows formally appointed to the College, Professor John Beattie and L.W. Proger who would both later become transiently involved in the operation of the Army Blood Transfusion Service (ABTS). Bristol was chosen as the location for the headquarters of the Service with the West Country of England as the donor recruitment area to meet both military and some civilian requirements, on the assumption, later to prove erroneous, that it would be unlikely to suffer air attack. The operation would have two branches, the Army Blood Supply Depot (ABSD) and the Overseas Blood Transfusion and Surgical Research Laboratory (BTSRL) to deliver transfusion services to the BEF in France and Flanders, through Dieppe. Beattie as Col. was appointed in overall command and Proger as Lt-Col. in command of the BTSRL. Col. Lionel Whitby was appointed as Commanding Officer of the ABSD in June 1939 with staff initially derived mainly from the Royal College of Surgeons and the Middlesex Hospital [67].

Staffing of Field Transfusion Units (FTU) to be deployed by the BTSRL was defined as one officer trained in transfusion, two orderlies and a driver [68]. Training programs were developed for transfusion officers at ABSD and during the militarily relatively inactive "phoney war" before May 10th 1940 extensive drills were carried out in the field by the FTUs attached to the British Expeditionary Force (BEF). Performance of the FTUs during the retreat and evacuation of May-June 1940 was regarded as generally satisfactory with about 400 units of blood administered during that operation. It became clear that the education and experience of the transfusion officer together with the practical skills of his team in providing effective and confident resuscitation warranted recognition as a "specialist" and enhancement of rank (and hence authority), and that the duties were beyond the abilities of a general duty medical officer $[67,69]$.

Following the evacuation of the BEF at Dunkirk, the over-ambitious BTSRL was disbanded, and replaced with "Base Transfusion Units", one for each major theatre of war as it developed, with the first in Egypt, as the point of origin for a regional supply chain for the eastern North African theatre [69]. The entire operation was consolidated under the command of Col. Whitby.

As the war progressed, the ABTS developed its methods of transfusion delivery, but in general preserving the practice of advanced resuscitation by FTUs prior to further evacuation and surgery for selected ("Group 1") cases, usually determined by the trained "transfusion officer" and defined as those requiring urgent resuscitation and transfusion prior to further evacuation [70]. The transfusion officer's resuscitation options included whole blood, liquid and freeze-dried plasma and crystalloid. In his reviews of the ABTS' performance Whitby repeatedly emphasized the importance of the role of the transfusion officer in the successful management of casualties. The performance of the ABTS and its further evolution are described in a series of publications [71-75]. Whitby [74] provides a chart of the blood supply arrangements for the battle of Mareth in Tunisia in March 1943 (Fig. 5) 


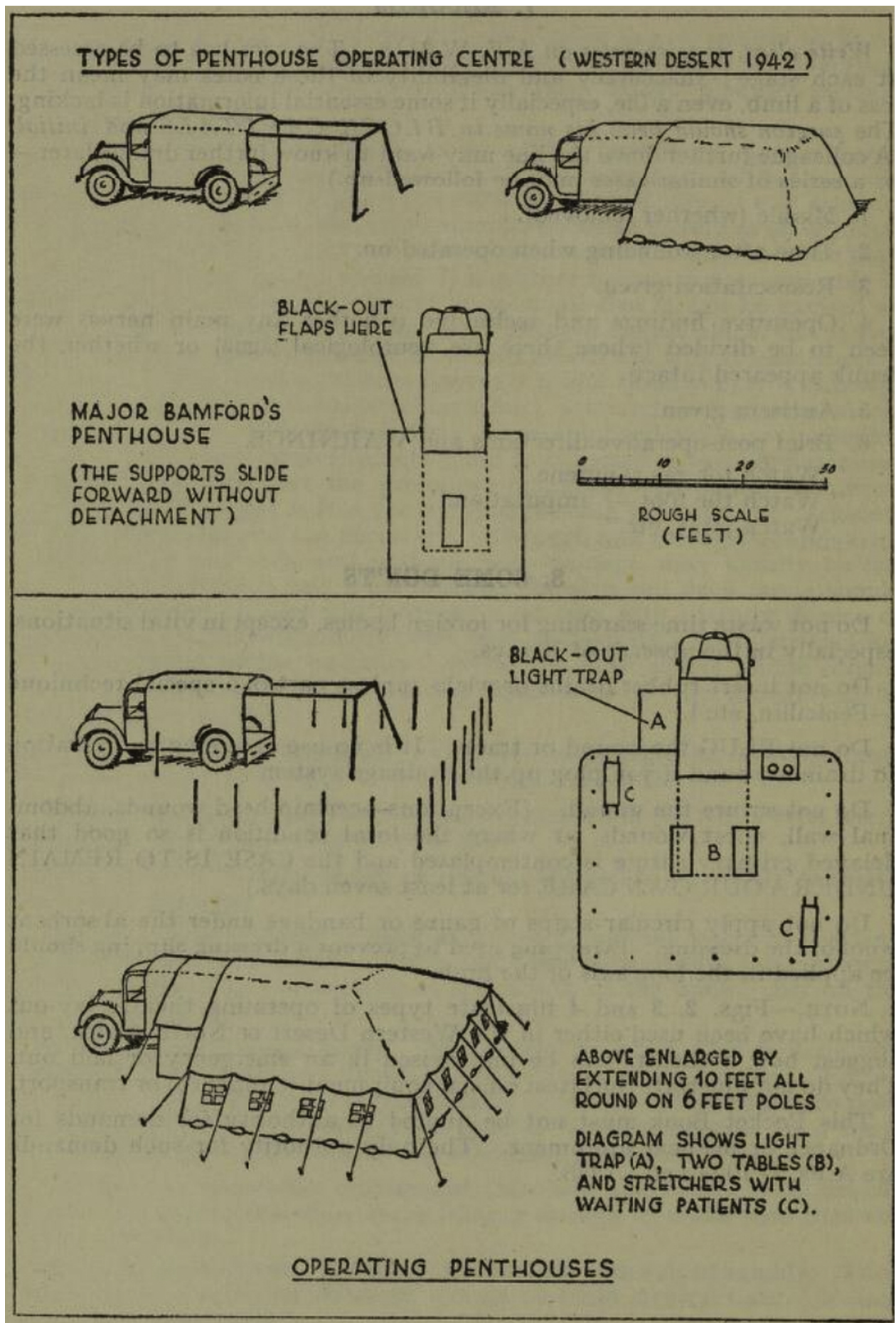

Fig. 6. Illustration of a mobile field surgical unit as used in the Western Desert (North Africa) campaign in 1942 [83]. A more modern version of the auto-chir. With permission, from The Museum of Military Medicine, Aldershot, England.

which shows a clear resemblance to Jolly's Three Point Forward system applied in Spain (Fig. 2). Also, the mobile self-contained surgical unit could be seen as analogous to the auto-chir adopted and expanded in Spain from original WW1 concept.

It is evident that the events of the Spanish Civil War were understood by the authorities planning and operating the transfusion services in anticipation of WW2 [59,72,76,77]. The information on the organization of the blood supplies from Barcelona [12-14] and Madrid [17], in addition to Duran's ongoing collaboration with Vaughan [10,64], contributed significantly to the success of the civilian Blood Supply Depots. Beattie and Whitby were both actively involved in the preparations for the civilian Blood Supply Depots and would have had the opportunity to learn from the experiences reported by Duran and Saxton, perhaps promoted by Vaughan, on transfusion operations during battles in Spain which could directly influence the military services in the field.

Saxton in his report on the Madrid Institute [17] provided the first account of his clinical use of transfusion, followed by reports on his mobile laboratory with its capacity to support transfusion at advanced mobile battlefield medical units [26] and on the evolution of his practices in transfusion over 2 years [27]. These provide some practical insight into the features and difficulties of his service but there does not 
appear to be any formal recognition of these contributions in the ABTS planning process.

In January 1939, the SMAC and the Socialist Medical Association arranged a reception for returning medical volunteers at B.M.A. House Tavistock Square, London, chaired in part by Janet Vaughan [78]. Among the speakers, Saxton discussed the "use of preserved blood for transfusion" which proved in subsequent questions to be of "special interest". Jolly also spoke and the text of his remarks survives [48]. He describes a Mobile Field Hospital as having 50-100 beds about $21 / 2-4$ miles behind the front, moving with the troop movements. Among his observations were the growth of the Army Medical Corps from a rudimentary, ill-equipped inadequate organisation to a disciplined effective body, and of the great advance in technique represented by the use of conserved blood for transfusion "on a large scale and delivered daily to the field". The attendance numbered about 200 [79] but no comprehensive list has been found of who of influence in the military planning process might have been present (besides Janet Vaughan) and the direct impact of the meeting is hard to assess.

Jolly subsequently wrote his textbook "Field Surgery in Total War" [47] describing his experiences in the Spanish Civil War. In it he describes his "Three-Point Forward System" made up of a Casualty Classification Post for Triage and determination for referral to the "No. 1 Hospital" for urgent treatment or, for the less urgent, referral to a more distant "No. 2 Hospital". The "Three Points" would move back and forth in a coordinated fashion as the fortunes of battle moved the front $[33,47,48]$. In endorsing this approach, Trueta [3] emphasized that distance between points should be measured in "minutes and not miles", in the interests of promoting prompt medical management of casualties. Jolly, with whom Saxton worked at Brunete and the Ebro, also discusses transfusion in some detail, advocating early transfusion even at Classification Posts if possible, and indicating the importance of designated transfusion officers. Specific mention is made of the contributions of Saxton and Duran.

The archival records of the history of the ABTS [67,69] and the various accounts in the medical literature cited here record little specific acknowledgement of the published contributions from the Spanish Civil War experience (nor of the medical literature in general) to the policies for the practices of the ABTS. It is, however, inconceivable that those planning the ABSD, BTSRL and later the ABTS were unaware of these published accounts. Furthermore, Janet Vaughan with her activist attitude and intimate knowledge of the situation and events in Spain, her involvement with transfusion in general and her connections to the MRC would be a forceful and knowledgeable advocate for appropriate policies arising from the Spanish experience. She and Whitby were each well aware of the others talents. They were involved together and with Beattie in the development of the London area Blood Supply Depots [62]. They contributed together, representing respectively the Civilian Medical Services and the Fighting Services, to the Report of the MRC Committee on Traumatic Shock [80], and had shared academic interests $[81,82]$.

Examining the structure of the ABTS, similarities to an idealized version of the Spanish experience emerge. The ABTS procurement and delivery structure is a much enlarged, sophisticated and far-reaching operation but operated on the same principles as the Spanish model. The delivery system in the field as illustrated for the Battle of Mareth in Tunisia in 1943 [74] bears a clear resemblance to what might be expected to support a "Three-Point Forward System" of triage evaluation and transfusion decision (Fig. 5). The FTU concept of a transfusion officer, orderlies and a driver, represents a more formal and structured version of Saxton's mobile laboratory and transfusion team, and the mobile surgical units deployed in North Africa [83](Fig. 6) resemble the concept of the auto-chir successfully applied in Spain [40,41]. To what extent these features would have been chosen independently and to what extent they were influenced by knowledge based on the Civil War experience itself remains debatable, but the necessary information was available, those in the decision-making process for the development of
Army transfusion policy and procedures clearly had access to knowledge of the Spanish experience: the outcome is suggestive, and the inference is clear.

The principles of casualty triage and prompt transfusion which evolved in the Spanish Civil War, and were consolidated in WW2, still inform the current debate among trauma specialists, military and civilian, about the delivery of transfusion support to the severely injured. A fuller biography of Dr. Douglas Jolly has recently been published [84].

\section{Declaration of Competing Interest}

Dr. Linda Palfreeman: No interest to declare.

Dr. Peter Pinkerton: No interest to declare

\section{Acknowledgements}

We are indebted to the following for assistance with documentation of various aspects of this review: Scott Davidson, Bethune House, Gravenhurst, ON, Canada for access to records of Dr. Reginald Saxton's visit to the Madrid Blood Transfusion Institute; Sheena Evans, independent scholar, for access to records of Dr. Janet Vaughan's meetings in connection with the pre-war development of Blood Depots in London; Dr. David Lowe for advice on the contributions of Dr. Douglas Jolly; Meirian Jump, Librarian, Marx Memorial Library, London, for access to copies of documents pertaining to Dr. Reginald Saxton and Dr. Douglas Jolly; Ray Parkes and Michael Cooper, for access to Dr. Saxton's correspondence with his mother.

We are grateful to Dr. Jeannie Callum and Lt.Col. Andrew Beckett for their constructive criticism and suggestions for improvement of this review.

\section{References}

[1] Coni N. Medicine and the Spanish Civil War. J Roy Soc Med 2002;95:147-50.

[2] Trueta J. "Closed" treatment of war fractures. Lancet 1939;1:1452-5.

[3] Trueta J. The principles and practice of war surgery. USA: C V Mosby Co., St Louis MO; 1943.

[4] Transfusion du Sang. Comptes-Rendus de la Conference Chirurgicale Interalliee pour L'Etude des Plaies de Guerre. 4th Session. Arch Med Pharm Milit 1918;70:123-85.

[5] Schneider WH. Blood transfusion in peace and war. 1900-1918. Soc Hist Med 1997; 10:105-26.

[6] Hess JR, Schmidt PJ. The first blood banker: Oswald Hope Robertson. Transfusion 2000; $40: 110-3$

[7] Pelis K. Taking credit: the Canadian Army Medical Corps and the British conversion to blood transfusion in WW1. J Hist Med Allied Sci 2001;56:238-77.

[8] Pinkerton PH. Canadian surgeons and the introduction of blood transfusion in war surgery. Transfus Med Rev 2008;22:77-86.

[9] Schneider WH. Blood transfusion between the wars. J Hist Med Allied Sci 2003;58:187-224

[10] Gunson HH, Dodsworth H. Fifty years of blood transfusion. Chapter 2: towards a National Blood Transfusion Service in England and Wales, 1900-1946. Transfus Med 1996;6(Suppl. 1):4-16.

[11] Fantus B. The therapy of Cook County Hospital; blood preservation. JAMA 1937:109:128-31.

[12] Duran Jordà F. El Servicio de Transfusión de Sangre de Barcelona. Técnicas y utillaje. Rev Sanidad Guerra 1937;1(8):307-21.

[13] Duran Jordà F. The Barcelona blood transfusion service. Lancet 1939;1:773-5.

[14] Saxton RS. Barcelona blood transfusion service. Lancet 1939;1:905.

[15] Lozano M, Cid J. Frederic Duran-Jordà; a transfusion medicine pioneer. Transfus Med Rev 2007;21:75-81.

[16] Lozano Molero M, Cid Vidal J. Frederic Duran Jordà: Centenario del nacimiento de un pionero de la hemoterapia. Sociedad Española de Transfusión Sanguínea 2005;56:2.

[17] Saxton RS. The Madrid blood transfusion institute. Lancet 1937;2:606-7.

[18] Franco A, Cortes J, Álvarez J, et al. The development of blood transfusion: the contributions of Norman Bethune in the Spanish Civil War (1936-1939). Can J Anaesth 1996;43:1076-8.

[19] Pinkerton PH. Norman Bethune and transfusion in the Spanish Civil War. Vox Sang 2002;83(Suppl. 1):117-20.

[20] Pinkerton PH. Norman Bethune, eccentric, man of principle, man of action, surgeon, and his contribution to blood transfusion in war. Transfus Med Rev 2007;21:255-64.

[21] Stewart R, Phoenix Stewart S. The life of Norman Bethune. Montreal, QC and 
Kingston. ON, Canada: McGill-Queen's University Press; 2011.

[22] Pittaluga G. Quelques considerations sur la transfusion sanguine pendant la guerre civile en Espagne, 1936-1939. Mem Adad Chirurgie 1939;65:1080-90.

[23] Saxton RS. A study of the Madrid Transfusion Service March 7 Gravenhurst, Ontario: Archives of Bethune House; 1937. Ref. No. X.75.15.1.

[24] Stewart R. The mind of Norman Bethune. Markham, ON, Canada: Fitzhenry and Whiteside Ltd.; 2002.

[25] Saxton RS. A hospital near Teruel. Lancet 1938;1:104.

[26] Saxton RS. A mobile laboratory in Spain. Lancet 1938;1:916.

[27] Saxton RS. Medicine in Republican Spain. Lancet 1938;2:751-2.

[28] Saxton RS. Imperial War Museum. Reginald Saxton (Oral History). Cat. No. 8735 1984-11. https://www.iwm.org.uk/collections/item/object80008531 (Accessioned January 7th 2019). 2019.

[29] Saxton RS. Interview with London Evening Gazette. Scrapbook relating to Reg Saxton. Marx Memorial Library; 1936. September, Doc. Ref. SC/VOL/RSA/3/1.

[30] Berkshire Chronicle. Medical Aid in Spain. Scrapbook relating to Reg Saxton. Marx Memorial Library; 1937. March $12^{\text {th }}$ Doc. Ref. SC/VOL/RSA/3/1.

[31] Boulton F, Roberts DJ. Blood transfusion at the time of the First World War practice and promise at the birth of transfusion medicine. Transfus Med 2014;24:325-34.

[32] Sinclair-Loutit KWC. An ambulance in Spain. Lancet 1936;2. 1295-6.

[33] Shirlaw GB, Troke C. Medicine versus Invasion. The Home Guard Medical Service in Action. London: Secker and Warburg, Ltd.; 1941.

[34] Stewart R, Majada J. Bethune in Spain. Montreal and Kingston, Canada: McGillQueens University Press; 2014. p. 52.

[35] Cazalaa J-B. The Henry and Jouvelet Transfusion Apparatus. Anesthesiology 2012;117:1189.

[36] Saxton RS. Personal correspondence to his mother, 1937-1938. Personal archive, courtesy of Ray Parkes and Michael Cooper.

[37] Palfreeman L. Spain Bleeds. The development of battlefield blood transfusion during the Civil War. Brighton, England: Sussex Academic Press; 2015.

[38] Dingle B. Blood Transfusion in Spain. Spanish Medical Aid Committee Archives 1938. Digital Collections. Doc. Ref. 292/946/42/13. Report, August (Accessioned 8th January 2019). https://wdc.contentdm.oclc.org.

[39] Spanish Medical Aid Committee Archives. Bulletin; 1938. August https:// wdc.contentdm.oclc.org Digital Collections. Doc. Ref. 292/946/42/18(iii). (Accessioned 8th January 2019).

[40] Coni N. Medicine and Warfare. Spain 1936-1939. New York, NY: Routledge, Taylor and Francis Group; 2008.

[41] Derby M, Jorge D. Moisès Broggi I Valles (1908-2012) Military surgeon and Catalan humanitarian. J Med Biog 2016;24:23-9.

[42] Spanish Medical Aid Committee Archives. March Bulletin; 1938. https://wdc.contentdm.oclc.org Digital Collections. Doc. Ref. 292/946/42/11(i). (Accessioned 8th January 2019).

[43] Saxton RS. A petrol-lit hospital. Dr. Saxton's difficult work. Berkshire Chronicle. Scrapbook relating to Reg Saxton. Marx Memorial Library; 1938. March $4^{\text {th }}$ Doc. Ref. SC/VOL/RSA/3/1.

[44] Yudin SS. Transfusion of stored cadaver blood. Practical considerations: the first thousand cases. Lancet 1937;2:361-6.

[45] Saxton RS. Towards cadaver blood transfusions in war. Lancet 1938;1:693-4.

[46] Saxton RS. Letter to JBS Haldane, $20^{\text {th }}$ June 1939. Wellcome Library. The JBS Haldane Papers; 1939. HALDANE/3/5/2/2/87 https://wellcomelibrary.org (Accessioned $7^{\text {th }}$ January 2019).

[47] Jolly DW. Field surgery in total war. London, England: Hamish Hamilton Medical Books; 1940.

[48] Jolly D. Republican Spain - 1936-1938. Text of talk to Reception at B.M.A. House (78). Marx Memorial Library. Doc. Ref. SC/VOL/OJO/17

[49] Grifols JR. The contribution of Dr. Duran-Jordà to the advancement and development of European blood transfusion. ISBT Sci Ser 2007;2:134-8.

[50] Obituary J. Trueta. Br Med J (Clin Res Ed) 1977;1:389.

[51] Typescript of the History of the Army Blood Transfusion Service 1939-1945. Royal Army Medical Corps Archives. Ref. RAMC/1816/6/2. Chapter IX. India. Roll of Honour. https://wellcomelibrary.org/item/b19546476 (Accessioned 7th January 2018).

[52] Palfreeman L. Salud! British volunteers in the Republican Medical Service during the Spanish Civil War, 1936-1939. Eastbourne, England: Sussex Academic Press; 2012.

[53] Duran Jordà F. Blood transfusion in the Spanish Civil War. British Red Cross Society Blood Transfusion Service; 1937. Quarterly Circular No. 15. April.

[54] Vaughan J. The anaemias. Oxford: Oxford University Press; 1934.

[55] Dacie J, Janet Maria (Dame) Vaughan. Royal College of Physicians, lives of the Fellows. Munk's Roll, IX 2019;541:1989-93. munksroll.rcplondon.ac.uk (Accessioned 8th January 2019).

[56] Whitby LEH, Britten CJC. Disorders of the blood. London: J \& A Churchill Ltd; 1935.

[57] Trail RR, Lionel Ernest Howard (Sir) Whitby. Royal College of Physicians, lives of the Fellows. Munk's Roll 2019;444:1926-65. Munksroll.rcplondon.ac.uk (Accessioned 8th January 2019).

[58] Britten CJC. Sir Lionel Whitby. Obituary. Blood 1957;12:400-1.

[59] Proger LW. Development of the emergency blood transfusion scheme. Lancet
1942;2:252-3.

[60] Vaughan JM. Imperial War Museum. Janet Vaughan (Oral History). Cat. No. 13796 1983-01. https://www.iwm.org.uk/collections/item/object/80013503 (Accessioned 7th January 2019). 2019.

[61] Spanish Medical Aid Committee. Minutes, May 25th 1938. Item 3. Special Correspondence. https://wdc.contentdm.oclc.org Digital Collections. Doc. Ref. 292/946/43/72. (Accessioned 7th January 2019).

[62] Vaughan Dame Janet. Emergency blood transfusion scheme for London and the home counties. 1939. Apr-Sep 1939. Doc. Ref. GC 186/1 Sheena Evans, personal communication.

[63] Elliott GA, Macfarlane RG, Vaughan JM. The use of stored blood for transfusion. Lancet 1939;1:384-7.

[64] Vaughan JM. War wounds and air raid casualties. Blood transfusion. Brit Med J 1939;1:933-6.

[65] Vaughan JM. The Medical Research Council blood transfusion outfit as provided for the sectors and depots in London and the home counties. Br Med J (Clin Res Ed) 1939;2:1084-5.

[66] Saxton RS. Blood transfusion. Lessons of service organised in Spain. Yorkshire Post. Scrapbook relating to Reg Saxton. Marx Memorial Library; 1939. January $27^{\text {th }}$ Doc. Ref. SC/VOL/RSA/3/1.

[67] Typescript history of the army blood transfusion service 1939-1945. 2019. Royal Army Medical Corps Archives Ref. RAMC/1816/6/2 https://wellcomelibrary.org/ item/b19546476 (Accessioned 7th January 2019).

[68] Beattie J. Circular memorandum. Subject - establishment of a blood transfusion team and duties. Ref. A.M.D.7.113A/39. November 27th, 1939. Typescript history of the army blood transfusion service 1939-1945. Royal Army Medical Corps Archives Ref.; 2019. RAMC/1816/6/3 https://wellcomelibrary.org/item/ b19546476 (Accessioned 9th January 2019).

[69] British expeditionary force in France and flanders. Royal Army Medical Corps Archives; 2019. Ref. RAMC/1816/6/1/3/4 https://wellcomelibrary.org/item/ b18894148 (Accessioned 7th January 2019).

[70] The treatment of wound shock. The medical research council: committee on traumatic shock and blood transfusion. $2^{\text {nd }}$ ed. London: RAMC/304 His Majesty's Stationery Office; 1944. (Accessioned 7th January 2019). https://wellcomelibrary. org/item/b18419902.

[71] Whitby LEH. The British army blood transfusion service. JAMA 1944;124:421-4.

[72] Whitby L. Transfusion in peace and war. Lancet 1945;1:1-4.

[73] Whitby L. The development and the results of transfusion in the treatment of battle casualties. J Roy Army Med Corps 1945;85:266-70.

[74] Whitby L. The transfusion of blood and other fluids. In: Cope Z, editor. History of the Second World War. Surgery. London: Blood Transfusion. Her Majesty's Stationery Office; 1953. p. 46-57 Chapter 2 (i).

[75] Conway H. The transfusion of blood and other fluids. In: Cope Z, editor. History of the Second World War. Surgery. London: Lessons learnt from experience of transfusion in the European battlefields. Her Majesty's Stationery Office; 1953. p. 58-65 Chapter 2 (ii).

[76] Annotation. Blood transfusion service for war. Br Med J (Clin Res Ed) 1939;2:15.

[77] Cowell EM. War wounds and air raid casualties. The prevention and treatment of shock. Br Med J (Clin Res Ed) 1939;1:883-5.

[78] Annotation. The war in Spain. Medical work for the Republic. Br Med J (Clin Res Ed) 1939;1:168-9.

[79] Spanish Medical Aid Committee. Item 2(b) matters arising Minutes, January $25^{\text {th }}$ https://wdc.contentdm.oclc.org Digital Collections Doc. Ref. 292/946/43/34. (Accessioned 7th January 2019). 1939.

[80] The Treatment of Wound Shock. The Medical Research Council: committee on traumatic shock and blood transfusion. RAMC/304 his majesty's stationery office. 1940. (Accessioned 7th January, 2019). https://wellcomelibrary.org/item/ b18419902.

[81] Whitby LEH, Vaughan J, Brown H. Discussion on the therapeutic value of transfusion of derivatives of blood. J Roy Soc Med 1941;34:257-66.

[82] Brown GL, Miles JAR, Vaughan JM, Whitby LEH. The effect of haemorrhage upon red cell size and red cell distribution. Br Med J (Clin Res Ed) 1942;1:99-102.

[83] A Field Surgery Pocket Book. Memoranda mainly based on experience in the present war. London: RAMC/50 The War Office; 1944. (Accessioned 7th January 2019). https://wellcomelibrary.org/item/b18366545.

[84] Derby M, Lowe D, Waddell Jolly Douglas. New Zealand pioneer of modern battlefield surgery. J Med Biogr 2018. https://doi.org/10.1177/0967772018754940.

Linda Palfreeman ${ }^{\mathrm{a}}$, Peter Pinkerton ${ }^{\mathrm{b}, *}$

${ }^{a}$ Faculdad de Educacion, Universidad CEU Cardinal Herrera, Elche, Spain ${ }^{\mathrm{b}}$ Division of Transfusion Medicine, Department of Laboratory Medicine and Molecular Diagnosis, Sunnybrook Health Sciences Centre and Department of Laboratory Medicine and Pathobiology, University of Toronto, Ontario,

Canada

E-mail address: peter.pinkerton@sunnybrook.ca (P. Pinkerton). 